Mr. sc. AMIR OBHOĐAŠ, viši arhivist

Hrvatski državni arhiv

Zagreb, Trg Marka Marulića 21

UDK 355.48(497.5)"1944"

94(497.5)"1944"

\title{
NOVA SAZNANJA O BORBAMA \\ U SJEVEROZAPADNOJ HRVATSKOJ 1944. \\ Pothvat „Brod“ i druga bitka za Ludbreg, srpanj 1944.
}

\begin{abstract}
APSTRAKT: Članak upotpunjuje postojeća saznanja o borbama u sjeverozapadnoj Hrvatskoj 1944. godine. Reč je o operaciji „Brod“ i drugoj bitci za Ludbreg, srpanj 1944. Pisan je na bazi novoobrađene arhivske građe u Hrvatskom državnom arhivu u Zagrebu.
\end{abstract}

Ključne reči: sjeverozapadna Hrvatska, operacija „Brod“, Ludberg, NOVJ, NDH, NOP, UDB-a.

Tijekom izučavanja operacija koje su se 1944. godine vodile na području sjeverozapadne Hrvatske, najveći problem s kojim smo se suočili bila je fragmentacija arhivskog građe koje se odnosi na Ustašku vojnicu. Smatrali smo da se ovo gradivo mora najvećim djelom nalaziti u Vojnom arhivu Republike Srbije u Beogradu (nekadašnji Vojni arhiv Vojnoistorijskog instituta), međutim, pokazalo se da se $\mathrm{u}$ onom dijelu arhivskih fondova koji su dostupni korisnicima nalazi samo manji dio dokumenata koji se odnose na djelovanje Ustaške vojnice.

Do ove fragmentacije je došlo njegovim korištenjem u različitim istražnim postupcima koje su nakon rada provodila različita jugoslavenska tijela. Primjerice, 1993. godine Ministarstvo unutarnjih poslova RH predalo je Hrvatskom državnom arhivu zbirku gradiva iz razdoblja NDH, koje se koristilo u navedene svrhe. Ova zbirka (HR HDA 1549, Zbirka zapisa upravnih i vojnih vlasti Nezavisne Države Hrvatske i Narodnooslobodilačkog pokreta) obuhvaća spise različite provenijencije, a koji nisu bili zanimljivi za uklapanje u tematsku povijesnu zbirku dokumenata Službe državne sigurnosti (nekadašnje UDB-e) ili u osobne policijske dosjee građana. Obrađena je posebnim sustavom indeksiranja, kojim su popisana sva imena koja se u sadržaju pojedinih dokumenata spominju, bez obzira na njihov značaj i kontekst. Spisi različite provenijencije međusobno su izmiješani, prvobitni 
je poredak u potpunosti narušen, te je stoga pretraživanje zbirke moguće jedino po kazalu imena. Kako zbirka sadrži 209 kutija tematski raznolikog gradiva vrlo je lako previdjeti ili preskočiti pojedine dokumente.

Tako smo u ovoj zbirci tek nedavno naišli na izvješća Poglavnikovog tjelesnog zbora (PTS). Stoga ćemo se u ovom članku koristeći se izvješćima I., II. i III. bojne 1. pješačke pukovnije PTS-a za mjesec lipanj i srpanj 1944. godine nastojati dodatno razraditi Pothvat „Brod“ i drugu bitku za Ludbreg. S ovim novim saznanjima upotpunićemo postojeća saznanja o borbama $u$ sjeverozapadnoj Hrvatskoj 1944. godine.

\section{Borbe na pravcu Koprivnica - Bjelovar i operacija Bienenhaus}

Nakon što su snage X. zagrebačkog zbora većim djelom izvukle s područja Zagorja i Kalnika prema Moslavini i Bilogori, u sjeverozapadnoj Hrvatskoj uslijedilo je relativno zatišje. Ovo zatišje potrajalo je do 18. lipnja kada je I. satnija/1. PTS bojna, pojačana jednom satnijom iz sastava III./1. PTS bojne i vodom gorskih topova DSŠ, zaprimila zapovijed da u zajednici s dijelovima V. stajaćeg djelatnog zdruga napadne selo Zrinski Topolovac $u$ kojem su se navodno nalazile dobro utvrđene partizanske snage. ${ }^{1}$ Pojačana I./1. PTS bojna istoga se dana rasporedila na crti Ladislav Sokolovački Gornji Križ, gdje je ulovila spoj s V. SDZ. Tijekom napredovanja prema Zrinskom Topolovcu naišlo se samo na manje raspršene partizanske grupe i selo je zauzeto u 10 sati bez borbe. Potom se I./1. PTS bojna povukla u Sokolovac, a kod sela Mala Mučna ponovno je naišla na manje skupine partizana koje nisu pružale jači otpor i odmah su se povukle prema Kalniku.

Tijekom odmora u Sokolovcu zapovjednik I./1. PTS bojne dobio je dojavu da se u Apatovcu nalazi stožer Kalničkog odreda s oko 120 partizana. ${ }^{2}$ U noći s 19. na 20. lipnja bojna je izvršila pokret pravcem Sokolovac Carevdar - Šužnjevići - Čabraji - Glogovnica - Grujice - kota 369 - Gradec i prije svanuća izbila pred Apatovac. Napad je u potpunosti iznenadio posadu u Apatovcu i nakon kraće borbe partizani su počeli odstupati prema selu Ivanec. Navodni partizanski gubici u ovoj borbi iznosili su 56 poginulih, ali kako o ovoj borbi nisam našao ni jedno izvješće NOVJ ovaj podatak ne mogu potvrditi. Tom prilikom zarobljeno je 27 puška, pismohrana zapovjedni-

\footnotetext{
${ }^{1}$ Hrvatska, Zagreb, Hrvatski državni arhiv, HR HDA 1549, Zbirka zapisa upravnih i vojnih vlasti Nezavisne Države Hrvatske i Narodnooslobodilačkog pokreta, spis III35/192-195, I. bojna 1. pukovnije PTS, Podhvatno izvješće za vrieme od 10/VI. do 1/VII. 1944. g.

2 Isto, vidi i Hrvatska, Zagreb, Hrvatski državni arhiv, HR HDA 1450, Zbirka mikrofilmova Gradivo iz inozemnih arhiva koje se odnosi na Hrvatsku, mikrofilmski svitak D-2364 (ZM 53b/244), snimak 501., Dnevno izvješće PTS-a, Ia, 20. 6. 1944.
} 
štva Kalničkog područja, ambulanta s mnogo lijekova, sustav veze i drugo vojničko tvorivo. U izvješću I./1. PTS bojne stoji da je zarobljen i jedan ranjeni partizanski časnik koji: „Dok je još težko ranjen ležao molio je liečničku pomoć da ga se spasi od smrti, jer da je On jedan od glavnih zapovjednika u Kalniku, a ime svoje nije htio kazati." Ovaj neidentificirani časnik kasnije je podlijegao zadobivenim ranama u bolnici u Ludbregu. Uspjehu ovog pothvata zacijelo je pridonijelo i to što je Kalnički odred morao predati svoje dvije bojne 32. diviziji NOVJ za popunu udarne brigade Braća Radić i njegovo brojno satnije u tom trenutku bilo je oko 100 boraca.

$\mathrm{U}$ isto je vrijeme $\mathrm{X}$ zagrebački korpus, koji je u prvoj polovici lipnja vodio teške borbe $\mathrm{u}$ okolici Bjelovara, težište svog djelovanja ponovno usmjerio prema Podravini, te je na području zapadne Bilogore razmjestio 32. diviziju NOVJ i 28. udarnu diviziju NOVJ. ${ }^{3}$ Dok su ove snage NOVJ bile u pokretu prema novo određenim položajima, dijelovi V. stajaćega djelatnog zdruga zauzeli su u noći s 19. na 20. lipnja Đurđevac. ${ }^{4}$ Pojedinosti o ovom pothvatu nedostaju i iz V. stajaćega djelatnog zdruga izvijestili su samo da su 20. lipnja zarobili jednu tešku strojnicu, šest lakih strojnica, 30 pušaka, alat puškarske radionice i drugo tvorivo uz vlastite gubitke od 2 poginula i 7 ranjenih. Nije poznato s kojom su se postrojbom sukobili ovi dijelovi V. SDZ, jer izvješća NOVJ o ovom sukobu nisam našao. U izvješću 28. udarne divizije navodi se samo da je Đurđevac zauzet od strane neprijatelja neposredno prije nego je u mjesto ušla njezina XXI. udarna brigada. ${ }^{5}$ Ova brigada o tomu nije bila obaviještena, te je 21. lipnja kod sela Budrovac vodila cjelodnevnu borbu s dijelovima V. SDZ iz Đurđevca.

Bila je to najava teških borbi koje će uslijediti u Podravini sljedećih tjedana. Dana 21. lipnja 32. divizija NOVJ razmjestila se na području Hudovljani - Maslarec - Donja Velika i već je 22. lipnja II./Braća Radić bojna došla u sukob s dijelovima V. stajaćega djelatnog zdruga koji su bili u izviđanju područja iznad Hudovljana. ${ }^{6}$ Sljedećeg dana, 23. lipnja, otpočeo je pothvat protiv snaga X. zagrebačkog zbora koje su se prikupljale na prostoru između Koprivnice i Bjelovara. Iz smjera Koprivnice nastupale su I./1. PTS bojna pojačana s 5. satnijom II./1. PTS bojne i VII./V. stajaća djelatna bojna, a iz smjera Bjelovara dijelovi njemačke 1. kozačke konjaničke divizije

${ }^{3}$ Rade Bulat, Deseti korpus „Zagrebački“ NOV I POJ, ČGP Delo, Ljubljana, 1985., str. 95. 28. udarna divizija NOVJ ušla je u sastav X. zagrebačkog zbora tijekom borbi u okolici Bjelovara, a 25. lipnja na područje Bilogore stigla je i I. zagorska brigada.

\footnotetext{
${ }^{4}$ Zbornik NOR-a, svezak V., knjiga 28., dokument br. 137., str. 693.-694.

${ }^{5}$ Zbornik NOR-a, svezak V., knjiga 29., dokument br. 39., str. 206.

${ }^{6}$ Zbornik NOR-a, svezak V., knjiga 29., dokument br. 18., str. 94.
} 
(1. Kosaken-Kavallerie-Division). ${ }^{7}$ Ove su snage trebale dovesti protivnika $\mathrm{u}$ okruženje na širem prostoru sela Poljančani. Tijekom napredovanja od sela Jagnjedovac prema Poljančanima, 5./1. PTS satnija naišla je kod sela Hudovljani na zasjedu udarne brigade Braća Radić, koja je držala položaj Donja Velika - Gornja Velika - Gornja Sredica - kota 230 - kota 220. ${ }^{8}$ Zasjeda je potisnuta jakom strojopuščanom vatrom i napredovanje je nastavljeno prema selu Gornje Sredice. Na čistini ispred sela udarna brigada Braća Radić izvršila je protunapad na pojačanu I./1. PTS bojnu, te su se razvile borbe prsa u prsa. Nakon teških borbi u kojima su se višekratno izmjenjivali napadi i protunapadi, I./1. PTS bojna uspjela je odbaciti udarnu brigadu Braća Radić i u 12,30 sati zauzeti selo. Kako spoj s ostalim postrojbama iz pothvata nije ostvaren, a ne zaprimivši nikakve daljnje zapovijedi, zapovjednik I./1. PTS bojne ustaški bojnik Branko Nališ donio je odluku da nastavi s napredovanjem preko sela Kapela prema Bjelovaru. Bojna je pod borbom stigla u Bjelovar u 20 sati, a njezini ukupni gubitci toga su dana iznosili 5 poginulih i 6 ranjenih. Gubitci udarne brigade Braća Radić u ovoj borbi iznosili su 11 poginulih i 22 ranjena. $^{9}$

Ustaški bojnik Nališ u svom izvješću navodi da je VII satnija /V. stajaće djelatne bojne bez borbe došla u Poljančane, a kako je I satnija 1. PTS bojna zbog borbe kod Gornjih Sredica kasnila u svom nastupu, povukla se nakon nekog vremena na svoj početni postav. Međutim, iz izvješća 28. udarne divizije NOVJ vidljivo je da je toga dana vodila s ovom bojnom borbu kod sela Gornje Zdelice. ${ }^{10}$ Prvotno je VII./V. stajaća djelatna bojna tijekom svog napredovanja naišla na stožer X. zagrebačkog zbora u selu Gornje Zdelice i u potpunosti ga iznenadila. Stožer se je povukao u neredu, pri če$\mathrm{mu}$ je izgubio dio pismohrane i knjigu sa šiframa, a dio partizana iz osiguranja je zarobljen. Neposredno nakon toga, u 8 sati, pred Gornje Zdjelice dolazi XXI. brigada iz sastava 28. udarne divizije NOVJ, koja je imala zapovijed da zatvori pravac od sela Mosti i Poljančani. Partizanska XXI./28. brigada prešla je iz hodnje $u$ obuhvatni napad s tri svoje bojne, dok je jedna ostala u pričuvi i uspjela je potisnuti VII./V. stajaću djelatnu bojnu iz Gor-

${ }^{7}$ HR HDA 1450, mikrofilmski svitak D-2364 (ZM 53b/244), snimak 509., Dnevno izvješće PTS-a, Ia, 24. 6. 1944. i HR HDA 1549, spis III-35/192-195, I. bojna 1. pukovnije PTS, Podhvatno izvješće za vrieme od 10/VI. do 1/VII. 1944. g.

${ }^{8}$ HR HDA 1549, spis III-35/196-206, II. bojna 1. pukovnije PTS, Izvještaj o izvršenim podhvatima i izvidjanjima u mjesecu lipnju 1944. i HR HDA 1450, mikrofilmski svitak D-1186 (ZM 51E/1), snimak 245., Štab XXXII. Divizije NOVJ, 24. lipnja 1944. u 7,40.

${ }^{9}$ HR HDA 1450, mikrofilmski svitak D-1186 (ZM 51E/1), snimci 246., Štab XXXII. Divizije NOVJ, Oper. broj 126/44., Dne 24. lipnja 1944.

${ }^{10}$ Zbornik NOR-a, svezak V., knjiga 29., dokument br. 39., str. 206. i Radojica Nenezić, Dvadeset osma slavonska NO udarna divizija: u sjeverozapadnoj Hrvatskoj i u dvije borbe za oslobođenje Ludbrega, Centar za kulturu i informiranje, Beograd 1990., str. 143-146. 
njih Zdelica prema selu Mosti. U napadu je vraćen dio izgubljene pismohrane i oslobođeno je nekoliko zarobljenika. Istodobno je XVII./28. udarna brigada vodila borbu s dijelovima 1. kozačke konjaničke divizije kod sela Rakitnica, i uspjela ih natjerati na povlačenje prema Bjelovaru. ${ }^{11}$

Izvješće 32. divizije NOVJ od 24. lipnja donosi slijedeće viđenje ovih borbi: ${ }^{12}$ „Uslijed jakog pritiska neprijatelja i iznenadnog napada, koji brigada nije očekivala od pravca Mostova i Poljančana s obzirom na jedinice XXVIII. divizije, Brigada se morala povući i povukla se je sa Sredica. Neprijatelj je nastupao dalje i kod Sredica došlo je do teških i krvavih borbi i poslije nekoliko juriša neprijatelj je uspio zauzeti selo, dok su se naši povukli na položaje oko sela." U kasnijem izvješću od 25. lipnja zabilježeno je sljedeće: ${ }^{13}$ "Borba je bila vrlo oštra, krvava na bliskom odstojanju, partizani su se izmiješali s ustašama i tom prilikom vršeno je nekoliko juriša i protujuriša, dosta neorganizovanih, u kojima su se naročito istakli pojedini borci. Neprijatelj je konačno uspio da odbaci naše snage iz Gor. Sredica, koje su tada zauzele položaje oko samog sela."

Izvješća 32. divizije NOVJ o ovim borbama sadrže dosta nedosljednosti i za neuspjeh u ovoj borbi njezino zapovjedništvo dio krivice pokušalo je prebaciti na 28. udarnu diviziju NOVJ, jer da nije na vrijeme zatvorila desno krilo udarne brigade Braće Radić. Međutim, ova tvrdnja teško je održiva s obzirom da se težište napada na udarnu brigadu Braća Radić nalazilo na pravcu od Jagnjedovca prema Gornjim Sredicima, gdje je nastupala I./1. PTS bojna. Bliža je stvarnosti ocjena istog zapovjedništva da dio krivice snosi i zapovjednik brigade koji: ${ }^{14}{ }^{4}$...nije držao Brigadu u rukama, nego su komadant i politkomesar i pom. politkomesara Brigade bili prvi jurišaći tako da su izgubili svaku preglednost nad Brigadom i situacijom na terenu operacije i nisu pravovremeno i ni pravromeno mogli ni primiti aktivniju pomoć našeg štaba, jer nas nisu u prvi mah kad im je pomoć bila najpotrebnija izvijestili." Ovoj ocjeni možemo dodati da i zapovjedništvo 32. divizije NOVJ snosi dio krivice jer da nije ostvarilo vezu s svojim i susjednim postrojbama i da je izgubilo preglednost nad bojištem. ${ }^{15} \mathrm{i}$

${ }^{11}$ Zbornik NOR-a, svezak V., knjiga 29., dokument br. 39., str. 206.

12 HR HDA 1450, mikrofilmski svitak D-1186 (ZM 51E/1), snimak 245., Štab XXXII. Divizije NOVJ, 24. lipnja 1944. u 7,40.

${ }^{13}$ HR HDA 1450, mikrofilmski svitak D-1186 (ZM 51E/1), snimci 248.-249., Štab XXXII. Divizije NOVJ, Oper. broj 127/44., Dne 25. lipnja 1944.

${ }^{14}$ Isto.

${ }^{15}$ Radojica Nenezić, Dvadeset osma slavonska NO udarna divizija, str. 145. Istovremeno kao uspjeh zapovjedništvo 32. divizije u izvješću od 25. lipnja navodi „Brigada je $i$ ako potiskivana od neprijatelja odstupala organizovano, bataljoni spremni za borbu i nisu bili razbijeni što je jedinstven slučaj za naše jedinice koju su se do sada kod povlačenja pred neprijateljem redovno rascjepkale". 
Slijedećeg se dana VII./V. stajaća djelatna bojna probila preko Gornjih Sredica i Pavlin Kloštra u Bjelovar. ${ }^{16}$ U tom trenutku 32. divizija NOVJ nalazila se razmještena na crti Peščenik - Gornji i Donji Maslarec - Gornji Križ - Jakopovac Kapelski ali nije ostvarila borbeni dodir s VII./V. stajaćom djelatnom bojnom. ${ }^{17}$ Da se ova se bojna uspjela probiti u Bjelovar bez borbe u izvješću 32. divizije NOVJ pravdali su to slabom vezom i koordinacijom s 28. udarnom divizijom NOVJ.

Pojačana I./1. PTS bojna i VII./V. stajaća djelatna bojna prikupile su se u Bjelovaru radi predstojeće operacije pod nazivom Bienenhaus (Košnica), koja je bila usmjerena protiv snaga NOVJ u široj okolici Čazme. Osim ove dvije bojne u operaciji Bienenhaus učestvovali su i dijelovi 1. kozačke konjaničke divizije i I. gorskog zdruga. ${ }^{18} \mathrm{U}$ iščekivanju operacije ove dvije bojne slijedeća su dva dana provela u odmoru te čišćenju opreme i naoružanja. ${ }^{19}$ U izvješću II./1. PTS bojne stoji da je 5./1. PTS satnija ova dva dana u Bjelovaru proboravila: ${ }^{20}$ „...bez hrane, čekajući dok se zapovjednici bojna nagode s Njemcima, jer su se odmetnički jaki djelovi prebacili na podrućje 1. pukovnije PTS. Medjutim njemački pukovnik, zapovjednik podhvata izjavio je da to njega ništa ne zanima, premda mu se dokazalo da se odmetnički djelovi ne nalaze više u području u kojem je trebao biti poduhvat pod njegovim zapovjedništvom."

Pojačana I./1. PTS bojna i VII./V. stajaća djelatna bojna uključile su se u operaciju 26. lipnja u 4 sata kada su otpočele napredovati pravcem Narta - Laminac - Bojana - Gornji Miklauš. Pred Gornjim Miklaušem došlo je do borbe slabijeg intenziteta sa snagama II./33. moslavačke brigade, a nakon zauzimanja sela ustaške su se snage povukle u Grabovnicu, gdje su se zadržale slijedeća dva dana. Pothvat je okončan 27. lipnja, a pojačana I./1. PTS bojna prebačena je 28. lipnja preko Čazme za Ivanić Grad, gdje je istog dana ukrcana na vlak za Ludbreg. Operacija nije postigla značajnijeg uspjeha, jer se glavnina 33. divizije NOVJ uspjela povući prema Kalniku pretrpjevši pri tom samo manje gubitke.

Tijekom ovog pothvata počinjeni su brojni zločini o čemu je ustaški nadporučnik Zvonimir Buljan, zapovjednik II./1. PTS bojne, izvijestio: ${ }^{21}$ „Vrlo loše su se ponieli u podhvatu pripadnici Crne legije koji su ulazili u kuće

${ }^{16}$ HR HDA 1549, spis III-35/196-206, II. bojna 1. pukovnije PTS, Izvještaj o izvršenim podhvatima i izvidjanjima u mjesecu lipnju 1944.

${ }^{17}$ Zbornik NOR-a, svezak V., knjiga 28., dokument br. 100., str. 521.

${ }^{18}$ Rade Bulat, Deseti korpus, str. 108.

19 HR HDA 1549, spis III-35/192-195, I. bojna 1. pukovnije PTS, Podhvatno izvješće za vrieme od 10/VI. do 1/VII. 1944. g.

${ }^{20}$ HR HDA 1549, spis III-35/196-206, II. bojna 1. pukovnije PTS, Izvještaj o izvršenim podhvatima i izvidjanjima u mjesecu lipnju 1944.

${ }^{21}$ Isto. 
uzimali privatne stvari, odjeću, obuću, na očigled vlastnika. U s. Grabovnica koje je bilo cielo u plamenu nije nidko živ zatečen. Na upit zašto su bježali odgovorili su da ne bi bježali ni pred ustašama ni pred partizanima ali moraju bježati pred kozacima jer isti pale i pljačkaju i siluju žene i djecu.

Kod ulazka u Čazmu bilo je još gorih prizora. Čitava Čazma bila je u jednom plamenu. Kozaci nisu pitali čija je koja kuća već su od reda palili i uništavali. Tako n. pr. kuća jednog ust. satnika povratnika izgorjela je zajedno sa njegovom majkom. Na drugom mjestu naišlo se na neku 75 godišnju staricu silovanu a potom usmrćenu nožem u ledja. Sve su to uradili kozaci. Kada je 5 sat krenula iz Čazme prema Ivanić gradu susretali su na povorke žena i djece koji su plakali bježeći prema Ivanić gradu, govoreći nam: 'Zašto ustaše dopuštaju da kozaci radi ovakve stvari."

O ovim postupcima 1. kozačke konjaničke divizije izvijestilo je i zapovjedništvo I. gorskog zdruga: „Prigodom ovog podhvata desili su se izgredi od strane kozačkih postrojbi na koje je ovaj zdrug reagirao tužbom sa svim potrebnim dokazima na najviše mjesto. Podhvat nije uspio kao što je trebao prema snagama koje su sudjelovale, radi kozačkih nedjela i radi slabo izdane zapovjedi za podhvat." 22

\section{Pothvat „Brod“}

Tako su se koncem lipnja 1944. godine na području Kalnika i Bilogore našle pod zapovjedništvom X. zagrebačkog korpusa 33. i 32. divizija NOVJ, 28. udarna divizija NOVJ, I. Zagorska brigada i Kalnički odred. Zapovjedništvo ovoga zbora namjeravalo je s ovim snagama ponoviti uspjeh od prošle godine i ponovno uspostaviti „Podravsku republiku“. Prvotno je bilo planirano da s 28. udarnom i 32. divizijom NOVJ zauzmu uporište $u$ Koprivnici, za što su od Glavnog štaba NOV i POH zatražili podršku zrakoplovstva, jer je procjena bila takva da bez zračne potpore ne mogu zauzeti ovo jako uporište. ${ }^{23}$ Kako Glavni štab nije mogao zajamčiti pružanje zračne potpore, zapovjedništvo X. zagrebačkog korpusa preusmjerilo je svoje snage na zauzimanje Ludbrega.

U sklopu priprema za napad minirani su mostovi između Ludbrega i Koprivnice, a na istom pravcu porušeno je i 3.500 metara pruge. Sukobi između ophodnji na ovom području postaju sve učestaliji te je tako kod Subotice Podravske 28. lipnja došlo do jačeg sukoba posade iz Koprivnice i brigade Matija Gubec, koja se razmjestila na uzvisine južno od ceste Kop-

${ }^{22}$ HR HDA 1450, mikrofilmski svitak D-2169 (ZM 53b/49), snimci 79.-96., Zapovjedničtvo I. zbornog područja, Obće bojne relacije I. zbornog područja za mjesec lipanj 1944. godine.

${ }^{23}$ Rade Bulat, Deseti korpus, str. 96. 
rivnica - Subotica Podravska. ${ }^{24}$ Do sukoba je došlo nakon što su u 6,30 sati dva motocikla s prikolicom naišla na partizansku zasjedu u kojoj su dva vojničara V. stajaćega djelatnog zdruga poginula, a dvojica su uspjela pobjeći. ${ }^{25} \mathrm{Na}$ to je iz uporišta u Koprivnici upućena jedna satnija ojačana dvama lakim tenkovima, koja se na visovima Leptan, Razbojište i kota 228 sukobila s III./Matija Gubec bojnom. Dok se vodila ova borba, II./Matija Gubec bojna nastojala je zaći u leđa ustaškoj satniji, što ju je primoralo da odstupi natrag prema cesti. Osim dvojice poginulih u zasjedi, V. stajaći djelatni zdrug u ovoj je borbi imao još tri smrtno stradala i četiri ranjena vojničara, dok su gubici u brigadi Matija Gubec bili jedan poginuli i četvorica ranjenih. Udarna brigada Braća Radić povukla se uvečer na položaj Ribnjak Radeljevo Selo - Prkos, a brigada Matija Gubec na položaj Vrhovac - Domaje. ${ }^{26}$ Ovome treba dodati i da je zbog zasjede kod Subotice Podravske, Vojni sud u Bjelovaru, kojim je predsjedao zapovjednik V. stajaćega djelatnog zdruga, ustaški dopukovnik Boban dao 30. lipnja strijeljati 26 partizanskih simpatizera. ${ }^{27}$

Ophodnje iz uporišta u Koprivnici i Ludbregu svakodnevno su javljale o premještanju snaga NOVJ prema Ludbregu te je stoga posada u Ludbregu pojačana 1. satnijom III./1. PTS bojne iz Ivanca i dvama oklopnim vozilima iz Varaždina. Po okolnim visovima otvarana je topnička vatra, a zatraženo je i djelovanje zrakoplovstva. U Ludbreg se 30. lipnja u 21 sat vratila iz Bjelovara I./1. PTS bojna, a s njom je došla i VII./V. stajaća djelatna bojna. ${ }^{28}$

Kako bi razbile snage NOVJ koje su se prikupljale na Kalniku i spriječile očekivani napad na Ludbreg u zapovjedništvu 1. pješačke pukovnije PTS-a odlučili izvršiti pothvat na području Apatovac - Rasinja. ${ }^{29}$ U pothvatu koji je nosio naziv „Brod" učestvovale su I./1. PTS bojna pojačana $s$ 14./1. topničkom satnijom, te tri satnije II./1. PTS bojne (5., 7. i 8.) pojačane 12. satnijom iz sastava III./1. PTS bojne, dvjema satnijama VII. hrvatske dobrovoljačke policijske bojne iz Varaždina i vodom gorskih topova DSŠ-

${ }^{24}$ HR HDA 1450, mikrofilmski svitak D-2364 (ZM 53b/244), snimci 518.-520., Dnevna izvješće PTS-a, Ia, 28. i 29.6.1944. U dnevnom izvješću PTS-a za 29. lipnja stoji da se je sukob vodio s 21. udarnom brigadom, ali je zapravo u pitanju bila brigada Matija Gubec.

${ }^{25}$ Zbornik NOR-a, svezak V., knjiga 28., dokument br. 97., str. 508.-509.

${ }^{26}$ Zbornik NOR-a, svezak V., knjiga 29., dokument br. 51., str. 282.

${ }^{27}$ Zvonimir Despot, Vrijeme zločina, str. 151.

${ }^{28}$ HR HDA 1450, mikrofilmski svitak D-2364 (ZM 53b/244), snimak 524., Dnevno izvješće PTS-a, Ia, 1. 7. 1944.

${ }^{29}$ Sjeverozapadna Hrvatska u Narodnooslobodilačkoj borbi i socijalističkoj revoluciji 1941-1945, Građa, svezak X., dokument br. 166. str. 833-834. 
a. ${ }^{30}$ Težište napada nalazilo se na pojačanoj II./1. PTS bojni, koja se 1. srpnja okupila u selu Ljubelj, od kuda je slijedećeg dana trebala napadati pravcem Apatovac - Rasinja, dok je I./1. PTS bojna trebala zatvarati pravac Lukovec šuma - selo Lukovec - Rasinja. Prema zapovjedi obje grupe trebale su se spojiti na području Rasinje 2. srpnja u 11 sati. Tijekom pothvata dvoje oklopnih kola iz sastava Oklopnog sklopa PTS-a osiguravala su cestu Čukovec - Bolfan - Cvetkovec - Rasinja. ${ }^{31}$

U tom trenutku jedinice 32. divizije NOVJ, kojima je bila podređena i I. zagorska brigada, nalazile su se pokretu i uvečer 1 . srpnja dosegle su crtu Svibovec - Donja Poljana - Leskovec Toplički, gdje su trebale osiguravati planirani napad 28. udarne divizije NOVJ na Ludbreg. ${ }^{32} \mathrm{Na}$ njihov prijašnji položaj razmjestila se 28. udarna divizija NOVJ, čija je XXI. udarna brigada zauzela položaje u okolici sela Prkos i Vrhovac s obje strane puta Veliki Poganac - Rasinja, a XVII. udarna brigada se razmjestila na prostoru Apatovac - Ivanec Ludbreški - Ribnjak - Veliki Poganac. ${ }^{33}$

U ranim jutarnjim satima 2. srpnja pojačana II./1. PTS bojna zauzela je bez borbe selo Stupe gdje se je podijelila u dvije kolone. Prvu kolonu činila je II./1. PTS bojna i dva gorska topa DSŠ, a drugu VII. hrvatska dobrovoljačka policijska bojna i 12./1. PTS satnija. Prva kolona napala je selo Apatovac pravcem Lipovac - Fičar - Kota 326, dok je druga napala selo s njegove zapadne i južne strane. Napad je otpočeo u 7,30 sati jakom topničkom i minobacačkom vatrom, a potom je pješaštvo II./1. PTS bojne u jurišu potisnulo protivnika iz sela. Zauzimanje Apatovca okončano je u 9,30 sati uz gubitak od jednog ranjenog vojničara. Partizanska I., III. i IV. bojna iz sastava XVII. udarne brigade povukle su se u neredu i ponovno su se prikupile tek oko 16 sati istoga dana, dok se je II./XVII. bojna uredno povukla prema položajima XXI. udarne brigade. ${ }^{34}$

Prema zapovjedi 1. pješačke pukovnije PTS-a grupa okupljena oko II./1. PTS bojne ponovno se podijelila na dvije kolone i u 10,30 sati II./1. bojna PTS pojačana jednim gorskim topom počela je napredovati smjerom Apatovac - Ivanec Ludbreški - Ribnjak, dok je preostali dio grupe napredovao smjerom Apatovac - Veliki Poganac - Veliki Gradičani - Rasinja. ${ }^{35}$

${ }^{30}$ Isto, dokument br. 155., str. 763., kao i HR HDA 1450, mikrofilmski svitak D2364 (ZM 53b/244), snimak 528., Dnevno izvješće PTS-a, Ia, 3. 7. 1944.

${ }^{31}$ HR HDA 1549, spis III-35/91-93, Oklopni sklop PTS, Izvješće o podhvatima za mjesec lipanj i srpanj.

${ }^{32}$ Zbornik NOR-a, svezak V., knjiga 29., dokument br. 51., str. 282.

33 Zbornik NOR-a, svezak V., knjiga 29., dokument br. 6., str. 28.-29. i Radojica Nenezić, Dvadeset osma slavonska NO udarna divizija: u sjeverozapadnoj Hrvatskoj i u dvije borbe za oslobođenje Ludbrega, Centar za kulturu i informiranje, Beograd 1990., str. 171.

${ }^{34}$ Radojica Nenezić, Dvadeset osma slavonska NO udarna divizija, str. 172.

${ }^{35}$ Sjeverozapadna Hrvatska u NOR, svezak X., dokument br. 166. str. 834-835. 
Odmah po izlasku prethodnice iz Apatovca II./1. PTS bojna zadobila je snažnu strojopuščanu vatru iz smjera Ivanca Ludbreškog. Pod zaštitom jake topničke i minobacačke vatra II./1. PTS bojna izvršila je napad na Ivanec s lijevog boka i čela ali je ovaj napad prekinuo protunapad II./XVII. bojne $u$ lijevi bok II./1. PTS bojne. Nakon što je odbijen partizanski protunapad zapovjednik II./1. PTS bojne, ustaški nadporučnik Zvonimir Buljan, odustaje od daljnjeg napredovanja po zadanom pravcu i zapovijeda da se obje kolone probiju preko Velikog Poganca za Rasinju.

Istodobno je I./1. PTS bojna prema planu zaposjela pravac Lukovec šuma - selo Lukovec - Rasinja u 11 sati gdje je dva sata čekala na spoj s II./1. PTS bojnom. ${ }^{36}$ Kako je II./1. PTS bojna zaustavljena kod sela Ivanec Ludbreški do ovog spoja nije došlo i desno krilo I./1. PTS bojne stajalo je nepokriveno. Stoga je njezin zapovjednik ustaški bojnik Branko Nališ zapovjedio da se s dosegnutog položaja napreduje u tri kolone na crtu Ivančec - Belanovo Selo - Rasinja, čime je nastojao olakšati napredovanje II./1. PTS bojne i ostvariti spajanje dviju grupa, ali je tijekom napredovanja došao u sukob s partizanskom I./XXI. i III./XXI. bojnom, koje su se nalazile razmještene na crti Radeljevo - Veliki Grabičani. ${ }^{37}$ Desne kolone I./1. PTS bojne zaustavljena je u samom početku svog nastupa čime je zaprijetilo opkoljavanje srednjoj koloni koja je prema planu izbila pred Belanovo selo. Desnoj koloni je iz Rasinje upućena 3./1. PTS satnija u pomoć koja je ujedno i pokrivala izvlačenje iz borbe srednje kolone. Pojačana I./1. PTS bojna okupila se ponovno u selu Rasinja, a sve borbe na ovom pravcu okončane su u 19,30 sati.

Dok su trajale ove borbe pojačana II./1. PTS bojna pokušala se je probiti cestom preko Prkosa prema Rasinji ali je pri tom naišla na snažnu vatru partizanske II./XXI. i IV./XXI. bojne razmještenima na postavu desno od ceste Veliki Poganac - Rasinja u šumi Gradina i Kamenjak. Grupa je zaustavljena pred selom Prkos, a istodobno je tučena i iz Pravca Ivanca Ludbreškog. ${ }^{38}$ Prkos je zauzet u 19 sati ali se stanje pojačane II./1. PTS bojne naglo pogoršalo nakon što su se dvije partizanske satnije iz sastava I./XXI. bojne i jedna iz sastava II./XXI. bojne ubacile u njezinu pozadinu i izvršile napad iz smjera Velikog Poganca. Povoz i topništvo cijelo su se to vrijeme nalazili na cesti pod su snažnom vatrom iz šume Gradina i Kamenjak, a protunapad VII. hrvatske dobrovoljačke policijske bojne nije uspio izbaciti partizansku II./XXI. i IV./XXI. bojne s ovih postava. U tom trenut-

${ }^{36}$ Sjeverozapadna Hrvatska u NOR, svezak X., dokument br. 155. str. 763-764.

37 Zbornik NOR-a, svezak V., knjiga 29., dokument br. 6., str. 29. Izvješće XXI. udarne brigade spominje da je I:/1. PTS bojna imala u potpori i dva tenka ali o tome ni $u$ jednom izvješću PTS-a nisam našao ni spomena.

${ }^{38}$ Sjeverozapadna Hrvatska u NOR, svezak X., dokument br. 166. str. 836-837. 
ku pojačanu II./1. PTS bojnu zahvatilo je rasulo i dio ljudstva počeo je bježati. Iako su časnici zadržali prisebnost i pokušavali okupiti ljudstvo i konje, to im nije pošlo za rukom te su topovi ostavljeni na cesti, a grupa se $u$ dijelovima i neredu povukla prema Ludbregu. Povlačenje je trajalo cijelu noć i glavnina II./1. PTS bojne okupila se u Ludbregu sutradan u 6 sati.

Pojačana II./1. PTS bojna u ovoj je borbi pretrpjela teške gubitke; poginulo je 12 pripadnika VII. policijske bojne, šestorica domobrana iz Domobranske središnje škole, dva vojničara II./1. PTS bojne i jedan vojničar iz 12./1. PTS satnije. ${ }^{39}$ Ranjeno je 5 vojničara II./1. PTS bojne, a 6 ih je nestalo, 12./1. PTS satnija imala je jednog ranjenog vojničara, dok se za ostale jedinice iz pojačane II./1. PTS bojne ne navode podatci. U prvi trenutak gubici su se činili još težim i prva izvješća javljala su da II./1. PTS bojna ima 20 poginulih i nestalih, VII. policijska bojna 60, a Domobranska središnja škola jednog časnika i 20 domobrana, ali se očito velik broj nestalih uspio naknadno vratiti u svoje postrojbe. ${ }^{40}$ Gubitci kod I./1. PTS bojne bili su znatno manji i iznosili su jednog poginulog vojničara i jednog ranjenog dočasnika, te dvojicu vojničara. ${ }^{41}$

U izvješću XXI. udarne brigade navodi se da su zarobljena dva topa $75 \mathrm{~mm}$, jedan minobacač $81 \mathrm{~mm}$, tri laka bacača, dvije teške strojnice, tri lake strojnice, dvije kratke strojnice, 30 pušaka, dvije brdske kuhinje, 12 konja te mnoštvo ostalog tvoriva. Gubici XXI. udarne brigade bili su trojica poginula i 13 ranjenih, dok se za XVII. udarnu brigadu navodi da je imala jednog poginulog i trojicu ranjenih. ${ }^{42}$

Zapovjedništvo Domobranske središnje škole u Varaždinu pokrenulo je istragu o gubitku brdskih topova u kojoj je ustanovljeno sljedeće:

„1. Da je kombiniranu-pojačanu bojnu, u čijem se sastavu nalazio vod gorskih topova ove škole, vodio jedan ustaški nadporučnik, koji u ovom slučaju nije pokazao dovoljno spreme i sposobnosti za svrsishodnu upotrebu voda gorskih topova i vodjenje bojne u obće.

Prema tome, trebala bi se iztraga proširiti u smislu priedloga povjerenstva, radi ustanovljenja, zbog čega je tolika snaga na najtežem i najvažnijem pravcu podhvata povjerena ustaškom nadporučniku, kada je u zapovjedništvu 1. pukovnije PTS-a bilo pogodnijih častnika.

${ }^{39}$ HR HDA 1450, mikrofilmski svitak D-2169 (ZM 53b/49), snimci 215.-218., Mjestno zapovjedničtvo Varaždin, 2196/taj., 7. VIII. 1944., Obća bojna relacija za mjesec srpanj 1944. godine i Sjeverozapadna Hrvatska u NOR, svezak X., dokument br. 166. str. 837.

${ }^{40}$ HR HDA 1450, mikrofilmski svitak D-2364 (ZM 53b/244), snimak 530., Dnevno izvješće PTS-a, Ia, 4. 7. 1944.

${ }^{41}$ Sjeverozapadna Hrvatska u NOR, svezak X., dokument br. 155. str. 764.

${ }^{42}$ Radojica Nenezić, Dvadeset osma slavonska NO udarna divizija, str. 171. 
2. Da se je satnija odredjena za neposrednu zaštitu topova u kritičnom trenutku odmah bez odpora razbjegla i taj vod topova ostavila nezaštićen, tako da je isti morao nakon kratke borbe, samoobrane i pokušaja spasavanja iste onesposobiti i napustiti.

Prema tome trebalo bi iztragom utvrditi krivičnu odgovornost zapovjednika sati za osiguranje voda topova.

3. Osim toga bilo bi potrebno iztragom utvrditi razloge zašto djelovanje snaga iz Ludbrega sa ovima kod Prkosa nije bilo uskladjeno, jer imadem dojam, da u tom cielom podhvatu, gdje su izgubljeni topovi, nije bilo jedinstveno rukovodjenje borbom.

Dostavljajući prednje, slobodan sam napomenuti, da je isto već drugi slučaj nepovratnog gubitka voda gorskih topova 7,5 cm. Obr. 28 u razmaku od 2 mjeseca čime je ova škola izgubila gorsku bitnicu (4 topa)“.

Naknadno je još dodano:

„1. Uobće vodjenje kombinirane II/1. pukov. P. T. S. ne odgovara trenutnim ondašnjim prilikama, kako se to vidi iz izvješća top. poručnika Slavka Grgurića.

2. Unatoč nepoznavanja situacije kod sela Prkos, nije provedeno razvidjanje, niti osiguranje desnog boka, te je time usliedio prepad partizana i gubitak topova.

3. Nije bilo jedinstvenog rukovodjenja niti medju djelovima kombinirane bojne, kao ni uskladjen rad s djelovanjem snaga iz Ludbrega" ${ }^{43}$

U svezi s ovim pothvatom je i sukob koji se dogodio u noći s 1 . na 2. srpnja u selu Svibovec. Naime zapovjednik posade u Varaždinskim Toplicima uputio je 1. srpnja u 16 sati jednu satniju Oklopnog sklopa PTS-a pravcem Varaždinske Toplice - Škarnik - Vidobornjak (kota 357) - Drobno Kamenje - Drenovac radi osiguravanja lijevog krila II./1. PTS bojne tijekom njezinog pokreta prema Apatovcu. ${ }^{44}$ Satnija je u Drenovac došla bez dodira s neprijateljem i u selu se zadržala do 2 sata kada je krenula natrag prema Varaždinskim Toplicama pravcem Glavica - kota 437 - Korović - Leskovac. Satnija je pri tom nezamijećeno prošla između položaja I. i III./Braća Radić bojne i u 3 sata u selu Svibovcu naletjela na II./Braća Radić bojnu. ${ }^{45}$ Satnija se pod borbom uspjela probiti prema Varaždinskim Toplicima ali uz znatne gubitke. U 8 sati prema Svibovcu upućene su dvije satnije Oklopnog sklopa PTS-a iz Varaždinskih Toplica koje su odstupile nakon što je na njih otvo-

${ }^{43}$ HR HDA 250, Ustaška vojnica, serija Poglavnikovi tjelesni zdrugovi, spis Ia-br. T. 1789/44., Izvješće po završetku iztrage o gubitku gor. topova.

${ }^{44}$ HR HDA 1549, spis III-35/91-93, Oklopni sklop PTS, Izvješće o podhvatima za mjesec lipanj i srpanj.

${ }^{45}$ Zbornik NOR-a, svezak V., knjiga 29., dokument br. 51., str. 282. 
rena vatra iz protuoklopnog naoružanja. ${ }^{46}$ Gubitci Oklopnog sklopa PTS-a bili su jedan časnik, dva dočasnika i pet vojničara poginuli ili nestalih, a udarna brigada Braća Radić imala je jednog poginulog i petoricu ranjenih. Međutim, u ovom napadu izgubljen je dio pismohrane 32. divizije NOVJ, što će kasnije u 28. udarnoj diviziji NOVJ pobuditi sumnju da su tom prilikom oružane snage NDH došle u posjed zapovjedi o napadu na Ludbreg. ${ }^{47}$

U noći s 3. na 4. srpnja brigada Matija Gubec napala je uporište u Novom Marofu koje je branila II./1. PTS bojna. ${ }^{48}$ Napad je trajao od 2 do 4 sata i posada Novog Marofa odbila ga je uz gubitak od trojice lakše ranjenih na vlastitoj strani, dok se u izvješću 32. divizije NOVJ gubici u ovoj borbi ne navode. ${ }^{49}$ U izvješću II./1. PTS bojne navodi se da se je borba većinom vodila s odstojanja a da je protivnik počeo odstupati u 3,30 u pravcu Možđenec - Ljubeščica. ${ }^{50}$ U gonjenje se upustila 8./1. strojnička satnija koja je uspjela zarobiti partizanskog potporučnika koji je pokušavao postaviti tri mine na potez ispod žičanog pojasa oko Novog Marofa.

\section{Borbe za Ludbreg}

S obzirom da su snage NOVJ počele sve više ugrožavati komunikaciju od Varaždinskih Toplica prema Ludbregu, zapovjednik PTS-a ustaški pukovnik Ante Moškov prebacio je iz Zagreba u Varaždinske Toplice tri satnije Dočasničkog tečaja PTS-a, a u Novi Marof jednu kombiniranu bojnu sastavljenu od 1./II. i 1./III. satnije Zagrebačkoga ustaškoga posadnog zdruga (ZUPZ) i 1./VII. satniju I. prometnog zdruga. ${ }^{51}$ Kako je 1./II. satnija ZUPZ-a činila posadu Marije Bistrice, na njezino mjesto postavljena je 8./III. satnija Stražarskog sklopa PTS-a.

$\mathrm{Na}$ ovaj način oslobodile su se snage 1. pješačke pukovnija PTS-a za pothvat čišćenja područja između Varaždinskih Toplica i Ludbrega, koji je otpočeo 5. srpnja u ranim jutarnjim satima. Napad se razvijao iz dvaju smjerova: II./1. PTS bojna i tri satnije Dočasničkog tečaja PTS-a nastupale su od Varaždinskih Toplica i Novog Marofa prema Drenovcu i Svibovcu, a

${ }^{46}$ HR HDA 1450, mikrofilmski svitak D-2364 (ZM 53b/244), snimak 530., Dnevno izvješće PTS-a, Ia, 4. 7. 1944.

${ }^{47}$ Radojica Nenezić, Dvadeset osma slavonska NO udarna divizija, str. 176.

${ }^{48}$ Zbornik NOR-a, svezak V., knjiga 29., dokument br. 51., str. 283.

${ }^{49}$ HR HDA 1450, mikrofilmski svitak D-2364 (ZM 53b/244), snimak 533., Dnevno izvješće PTS-a, Ia, 5. 7. 1944.

${ }^{50}$ Sjeverozapadna Hrvatska u NOR, svezak X., dokument br. 166. str. 840.

${ }^{51}$ HR HDA 1450, mikrofilmski svitak D-2364 (ZM 53b/244), snimak 530., Dnevno izvješće PTS-a, Ia, 4. 7. 1944. 
I./1. i III./1. PTS bojna od Ludbrega prema Leskovcu i Svibovcu. ${ }^{52}$ U 3 sata III./1. PTS bojna krenula je iz Ludbrega pravcem Vinogradci - Liepa Gorica - uzvisina Medved (kota 333), gdje se je sukobila s jednom satnijom I. zagorske brigade, a u uz nju su se još nalazile i stožerne postrojbe 32. divizije NOVJ, bolnički vod i dočasnička škola. ${ }^{53}$ Napad je u potpunosti iznenadio partizanske snage koje su se povukle $u$ neredu, a bolnički vod pritom je ostao bez sanitetskog tvoriva. Postrojbe PTS-a produžile su napad i ubrzo je čitava I. zagorska brigada potisnuta u selo Višograd na pravac kojim je nastupala I./1. PTS bojna. Ova je bojna nastup otpočela u 2 sata i kretala se pravcem Ludbreg - Hrastovsko - Slanje - kota 175 - Duga greda - kota 292 - Tri Međe - uzvisina Piramida gdje je prispjela u 7,30. S ove uzvisine jasno su se mogle vidjeti snage I. zagorske brigade $u$ odstupanju iz Višograda prema Drenovcu. Uslijedio je napad I./1. PTS bojne pravcem brdo Piramida - Višograd u kojem je I. zagorska brigada potisnuta na položaj II./Braća Radić bojne na brdu Glavica (kota 437).

Napredovanje II./1. PTS bojne odvijalo se nešto sporije. Ova je bojna krenula iz Novog Marofa u 3 sata i kretala se pravcem Možđenec - Ivanovo Polje - Kozji hrbet - kota 426 - Drenovac gdje je naišla na postav I. i III./Braća Radić bojne. Nakon kraće borbe partizanske su bojne potisnute prema Glavici, a istodobno je iz smjera Višograda po ovim snagama otvorena topnička i minobacačka vatra. Pred ovim napadom udarna brigada Braća Radić, I. zagorska brigada i stožerne postrojbe povukle su se prema Piramidi koja je ostala nezaposjednuta od strane PTS-a.

Snage PTS-a spojile su se na podruju Leskovca i Svibovca gdje su se sukobile s brigadom Matija Gubec kod Gornjeg Polja. Nakon kratke borbe brigada Matija Gubec povukla se prema Vrbanovcu, a postrojbe PTS-a vratile su se u svoja uporišta u Varaždinskim Toplicama, Novom Marofu i Ludbregu. Postrojbe PTS-a imale su u ovom pothvatu jednoga poginulog i trojicu ranjenih, a zarobljen je jedan teški minobacač, četiri teške strojnice i dvije lake strojnice. ${ }^{54}$ Izvješće 32 . divizije NOVJ navodi gubitke od jednoga poginuloga i desetorice ranjenih.

Bez obzira na ove borbe i izvješća o pojačanjima koja su pristigla posadi u Ludbregu, zapovjedništvo X. zagrebačkog zbora donijelo je odluku da se napad na Ludbreg nastavi prema planu. ${ }^{55}$ Uvodni dio zapovijedi za napad na Ludbreg pisan je u nadasve dramatičnom tonu, što u postrojbama

${ }^{52}$ Sjeverozapadna Hrvatska u NOR, svezak X., dokument br. 155. str. 765., dokument br. 161. str. 808. i dokument br. 166. str. 842 .

${ }^{53}$ Zbornik NOR-a, svezak V., knjiga 29., dokument br. 51., str. 284.

${ }^{54}$ HR HDA 1450, mikrofilmski svitak D-2364 (ZM 53b/244), snimak 535., Dnevno izvješće PTS-a, Ia, 6. 7. 1944.

${ }^{55}$ Rade Bulat, Deseti korpus, str. 101. 
NOVJ inače nije bila iznimka: „Jedinice X. korpusa 'Zagrebačkog' NOV i POJ i jedinice XXVIII. Udarne Divizije NOVJ započinju svoju ofenzivu na neprijatelja, koji je privremeno zaposjeo nekoliko većih uporišta u Podravini. Neprijateljske posade u tim uporištima sastavljene su od najkrvavijih ustaških razbojnika, koji su poharali i popalili mnoge naše krajeve. Opustjela i pogorjela sela Kalnika, ne pokošene livade i brojni grobovi koji vape za osvetom, djelo su tih ustaških hordi, koje već nekoliko mjeseci žare i pale na našem oslobodjenom teritoriju, pod vodstvom najvećeg Pavelićevog krvoloka Bobana. Polazimo u borbu da im se osvetimo i da ih uništimo. U času kada se obruč oko Hitlerove Njemačke steže ne smanjenom brzinom sa svih strana mi polazimo u borbu sa čvrstim uvjerenjem da će pobjeda biti naša i da će sva garišta i sve suze biti krvavo osvećene. Borci slavom ovjenčanih brigada XXVIII. Ud. Divizije, koji su prošle jeseni oslobodili Koprivnicu i Ludbreg uz pomoć boraca XXXII. i XXXIII. Divizije, sijati će opet smrt u redovima neprijatelja. Narod oko Ludbrega željno očekuje slobodu i sjeća se XVII. Udarne Brigade, koja će ga ovaj puta ponovo da oslobodi. “56

Jedinice 32. divizije bile su zadužene za osiguranje smjera od Varaždina i Varaždinskih Toplica, stoga su se u noći s 5. na 6. srpnja premjestile na nove položaje; udarna brigada Braća Radić zauzela je postav Čičkovina Hrastovljan, brigada Matija Gubec raspoređene je u okolicu Vrbanovca, a I. zagorska brigada crtu Leskovac - kota $295 .{ }^{57} \mathrm{Za}$ napad na samo mjesto određena je XVII. udarna brigada, a XXI. udarna brigada i XXV. brodska brigada osiguravale su pravac iz smjera Koprivnice. Zapadna grupa odreda osiguravala je smjer od Križevaca.

Posada Ludbrega sastojala se od I./1. i III./1. PTS bojne, 14./1. topnička satnija PTS-a, vod haubica DSŠ i VII./V. bojne Crne legije. ${ }^{58}$ Samo mjesto bilo je dobro utvrđeno sustavom bunkera međusobno povezanih rovovima i zaštićenih redovima bodljikave žice, a brdo Filipsberg na Ludbreškim Vinogradima bilo je utvrđeno za kružnu obranu. Ovo brdo nadvisuje sve uzvisine južno od grada i s njega se mogu nadzirati svi prilazi gradu s južne i zapadne strane. Sam Ludbreg držala je I./1. PTS bojna, dok je dio VII./V. bojne bila razmještena u zgradi Ciglane i brdu Flipsberg. Topništvo je bilo razmješteno sjeverno od starog groblja, između ceste za Varaždin i ceste koja vodi prema Varaždinskim Toplicama, a pričuvu je tvorila III./1. PTS bojna. Obranom je zapovijedao zapovjednik I./1. PTS ustaški bojnik

${ }^{56}$ HR HDA 1450, mikrofilmski svitak D-1186 (ZM 51E/1), snimci 63.-64., Štab X. korpusa „Zagrebačkog“ N. O. V. i P. O. J., op. broj 341., 29. VI. 1944., Zapovjest.

${ }^{57}$ Zbornik NOR-a, svezak V., knjiga 29., dokument br. 51., str. 285.

58 Sjeverozapadna Hrvatska u NOR, svezak X., dokument br. 155. str. 765-766., dokument br. 161. str. 811. i Radojica Nenezić, Dvadeset osma slavonska NO udarna divizija, str. 235-241. 
Nališ, a stožer mu se nalazio u zgradi kina (nakon rata preuređeno $u$ hotel Putnik).

Jedinice XVII. udarne brigade zauzele su napadne položaje u 0,50 sati 6. srpnja. ${ }^{59}$ Težište napada nalazilo se na III./XVII. bojni koja je napadala na južnom pravcu iz smjera sela Kučan prema zgradi mlina. Njezina 1. satnija uspjela je nezamijećeno otvoriti prolaz kroz žičane prepreke i u 1,30 zauzeti su prvi rovovi na južnom ulazu u grad. Ubrzo je zauzet drugi i treći rov nakon čega su uklonjene žičane prepreke i otvoren je prolaz za ulazak u Ludbreg. U 2 sati zapovjednik III./XVII. bojne Mojica Birta s 2. i 3. satnijom zauzima jedan bunker i nekoliko prvih kuća s obje strane ulice prema Varaždinskim Toplicama i nastavlja prodor prema topničkom postavu. Zapovjednik 28. udarne divizije Radojica Nenezić zapovijeda da se ovaj pravac pojača s tri satnije iz sastava II./XVII. bojne. Njezina 2. satnija preuzela je osiguranje lijevog boka prodora zajedno s 2. satnijom IV./XVII. bojne, a 1. satnija III./XVII. bojne ostaje u zauzetim rovovima i osigurava desni bok.

$\mathrm{U}$ isto vrijeme s napadom je otpočela i IV./XVII. bojna na sjevernom pravcu od sela Selnik prema željezničkoj stanici. I ova bojna uspjela je nezamijećeno otvoriti prolaze kroz žičane zapreke te potom napasti željezničku stanicu i bunkere na cesti koja vodi prema selu Selnik. ${ }^{60}$

${ }^{59}$ Radojica Nenezić, Dvadeset osma slavonska NO udarna divizija, str. 215-217.

${ }^{60}$ Isto, str. 254. O samom tijeku napada na željezničku postaju svjedočio je nakon rata Svetozar Jeremić-Baja, politički delegat voda u 3. satniji IV. bojne: „Zadatak naše čete je bio da napadne železničku stanicu Ludbreg i magacin pored iste, zatim da likvidira bunker na desnom krilu i dalje produži dejstvo. Napad je počeo u 01.00 ili 01.30 časova, sečenjem žice. Za vreme sečenja žice na nas nije opaljen ni jedan metak. Po pravljenju prolaza kroz žicu otvoren je plotun u pravcu rovova, a zatim smo se počeli prebacivati kroz napravljeni otvor i zauzimati rovove. Na nas ni tada nije opaljen ni jedan metak. Kod zauzimanja rovova naišli smo na jedan puškomitraljez, za koji ja danas tumačim, da je možda namerno ostavljen sa ciljem da se izazove naše oduševljenje o lakoći proboja i da nas se eventualno uvede u zamku. Po zauzimanju rovova prešli smo prugu i došli do magacina. Moj vod je zauzeo položaj. U međuvremenu, određeno je jedno odeljenje da očisti rovove i zauzme bunkere na desnom krilu, odakle je pružen vrlo jak otpor, pa taj zadatak nije izvršen. U toku borbe do nas je dolazio drug Milan Rodić, koji je naredio da se zauzmu položaji i sačeka dalje naređenje za produženje napada. Na dostignutim položajima prilično smo se zadržali, a na postavljeno pitanje komandiru čete, drugu Rodiću, zašto čekamo, odgovorio je, da ne možemo ići napred dok Prva četa ne osvoji bunkere na cesti za Selnik i time nam obezbedi bok i pozadinu. U međuvremenu, u cik zore, primetili smo komešanje ispred naših položaja. Drug Rodić je pitao: 'Ko je tamo?' 'Ovde ustaša Grga'. A istog trenutka je na nas otvorena uraganska vatra, sa čela i boka. Verovatno ceneći situaciju, a raspolažući i drugim podacima drug Rodić je naredio povlačenje. Povlačenje je vršeno organizovano pod borbom. Van žice je postavljen mitraljez na neki štagalj (senik), kojim se štitilo prebacivanje naših boraca. Tada je ranjen drug Rodić, kroz torbicu u desnu slabinu. Magacin i železnička stanica bili su u našim rukama, a moj vod nije išao dalje. Nismo prešli ni cestu pozadi magacina. Prestanak borbe bio je oko 6-7 časova. Bio je potpun dan." Isto, str. 255. 
U izvješću I./1. PTS bojne stoji da partizanska IV./XVII. bojna nije uspjela zauzeti zgradu stanice i da su tri partizana koja su se privukli zgradi ostala ležati pred njom. ${ }^{61}$

Slično je prošao i napad I./XVII. bojne koja je trebala zauzeti brdo Filipsberg i željeznički most preko Bednje, te potom zauzeti oružničku postaju, stožer I./1. PTS bojne i njezino skladište. Ova bojna nije uspjela ostvariti otvore kroz žičane prepreke, te iako se probila u zaleđe uzvisine Filipsberg, brdo nije uspjela zauzeti, jer je ovo najstrmiji pravac kojeg je inače teško svladati i bez borbe. Tako se I./XVII. bojna našla ukliještena između uporišta Ludbreg i uporišta na Ciglani te brdu Filipsberg bez mogućnosti daljnjeg napredovanja.

U 4,10 počeo je nakon jake topničke i minobacačke pripreme protunapad 9., 10. i 11. satnije III./1. PTS bojne na južnom pravcu proboja, a 12. satnija pojačala je postav I./1. PTS bojne kod željezničke stanice na sjevernom pravcu proboja. ${ }^{62}$ Protunapad na južnom pravcu presjekao je prodor u njezinoj osnovici, razdvojio 2. i 3. satniju III./XVII. bojne od II./XVII. bojne i doveo ih u potpuno okruženje. Topništvo iz uporišta otvorilo je zaprečnu vatru, a kako je počelo svitati pojačavala se vatra iz Ciglane i uporišta na Filipsbergu. U 5 sati III./1. PTS bojna počela je potiskivati partizanske snage iz zauzetih rovova na južnim prilazima gradu, dok je otpor dviju opkoljenih partizanskih satnija bivao sve slabiji. Partizanske snage izvršile su u 5,10 sati protunapad kako bi oslobodile snage u okruženju ali je ovaj napad odbijen i u 6,30 sati zapovjednik 28. udarne divizije NOVJ donosi odluku o povlačenju. ${ }^{63}$ Jedinice XVII. udarne brigade tijekom povlačenje bile su zasipane snažnom vatrom i tom je prigodom smrtno pogođen metkom $u$ potiljak zapovjednik II./XVII. bojne Dušan Popović. Postrojbe na osiguranju nisu vodile borbu i oko 10 sati počele su se povlačiti prema Kalniku. ${ }^{64}$

S opkoljenim dijelovima III./XVII. bojne u gradu borba se vodila do 11 sati i u izvješću I./1. PTS bojne stoji da: ${ }^{65}, \ldots . . s u$ se oni grozno branili i kako je koji streljivo istrošio tako bi se ta kuća zauzela i posada zarobila - preko čitavog dana vršen je pretres kuća na tom sektoru - pronađeno je mnogo živih tog bataljona. Sve što je živo uhvaćeno odmah je streljano."

Izvješća I./1. i III./1. PTS bojne navode da su imali ukupno 16 smrtno stradalih i 41 ranjenog pripadnika, a da su zarobljena 3 laka minobacača, 20 lakih strojnica, 96 pušaka i veća količina streljiva i raznog drugog

${ }^{61}$ Sjeverozapadna Hrvatska u NOR, svezak X., dokument br. 155. str. 766.

${ }^{62}$ Sjeverozapadna Hrvatska u NOR, svezak X., dokument br. 155. str. 766., dokument br. 161. str. 811 .

${ }^{63}$ R. Nenezić, Dvadeset osma slavonska NO udarna divizija, str. 219-220.

${ }^{64}$ Zbornik NOR-a, svezak V., knjiga 29., dokument br. 6., fusnota 2.

${ }^{65}$ Sjeverozapadna Hrvatska u NOR, svezak X., dokument br. 155. str. 766. 
vojničkog tvoriva. Za VII./V. bojnu nemamo podataka o gubitcima ili zaplijenjenom tvorivu.

Izvješća 28. udarne divizije NOVJ navodi sljedeće gubitke: I./XVII. bojna: jedan poginuo i devetorica ranjenih, II./XVII. bojna: četvorica poginula i desetorica ranjenih, III./XVII. bojna: 78 poginulih i nestalih i 21 ranjen i IV./XVII. bojna: 16 mrtvih i 26 ranjenih. ${ }^{66}$ Od III./XVII. bojne ostalo je na broju samo oko 60 ljudi. ${ }^{67}$

Za neuspjeh i pretrpljene velike gubitke zapovjednik 28. udarne divizije NOVJ Nenezić smatrao je najodgovornijim stožer X. zagrebačkog korpusa, tj. njegovog zapovjednika generala Vladu Matetića i komesara zbora pukovnika Ivana Šibla. ${ }^{68}$ Naime, prema saznanjima X. zagrebačkog korpusa posada u Ludbregu sastojala se od 250 ljudi, dok je zapovjedništvo 28. udarne divizije NOVJ izviđanjem utvrdilo da se u Ludbregu nalaze znatno veće protivničke snage. Ova izvješća potvrdila je i zapovijed o izvođenju pothvata "Brod“ koju je u borbama od 2. srpnja zaplijenila XXI. udarna brigada. Iz ove se zapovijedi moglo razaznati da se u Ludbregu i okolnim uporištima nalaze znatno veće snage od onih koje je navodilo zapovjedništvo X. zagrebačkog korpusa. Međutim, izvješća 28. udarne divizije NOVJ nisu uzimana u razmatranje i napad na Ludbreg izveden je prema prvobitnom planu. Razlog zbog kojeg je zapovjedništvo X. zagrebačkog korpusa toliko inzistirao na zauzimanju Ludbrega nalazio se u njegovoj želji za ponovnom uspostavom „Podravske republike“, a za što je zauzimanje Ludbrega i Koprivnice bile osnovni preduvjet.

Nenezić, osim toga, zamjera zapovjedništvu X. zagrebačkog korpusa što nije ga nije izvijestio o napadu na stožer udarne brigade Braća Radić u Svibovcu 2. srpnja i gubitku dijela pismohrane 32. divizije NOVJ, jer da je tom prilikom neprijatelj navodno došao u posjed zapovijesti za napad na Ludbreg. On smatra da je tako posada Ludbrega imala dovoljno vremena za pripremu obrane i da je namjerno dozvolila prodore $u$ grad na pojedinim mjestima kako bi nadmoćnijim snagama okružila i uništila partizanske jedinice. U izvješćima oružanih snaga NDH nisam naišao na potvrdu ove tvrdnje, a iz izvješća Oklopnog sklopa PTS-a vidi se da je do sukoba u Svibovcu došlo neplanirano i u njemu se ne spominje da su zarobljeni bilo kakvi dokumenti. Moguće je da je posada Ludbrega odista očekivala napad, na što upućuje lakoća s kojom su se partizanske snage probile kroz žičane prepreke na južnom i sjevernom prilazu i silovitost protunapada koji je potom uslijedio, a i pojedini učesnici napada svjedočili su o eksplozijama u zauzetim

${ }^{66}$ Zbornik NOR-a, svezak V., knjiga 29., dokument br. 40., str. 211.

${ }^{67}$ Zbornik NOR-a, svezak V., knjiga 29., dokument br. 6., fusnota 2.

${ }^{68}$ Ovoj problematici posvećen je skoro čitav drugi dio knjige Radojica Nenezić, Dvadeset osma slavonska NO udarna divizija. 
rovovima koje nisu poticale od minobacačke ili topničke vatre već od mina položenih u rovovima. Naznaka da je napad iščekivan može se iščitati iz izvješća ustaškog pukovnika Ante Moškova njemačkom LXIX. korpusu, u kojem se navodi da su partizanske snage prilikom napada na Ludbreg poražene primjenom taktike iznenađenja i varke. ${ }^{69}$ To, međutim, ne znači nužno da su u oružanim snagama NDH do saznanja o napadu na Ludbreg došli zapiljenom dokumenata. Prikupljanje partizanskih snaga nije prošlo nezamijećeno i obavještajna služba PTS-a raspolagala je s točnim saznanjima koje se sve postrojbe NOVJ nalaze na području njezinog djelovanja, stoga je i mogla pravodobno pripremiti obranu najvjerojatnijih ciljeva partizanskih napada. Slažem se, međutim, s Nenezićevom ocjenom da je planiranje napada na Ludbreg od strane zapovjedništva X. zagrebačkog korpusa bilo neadekvatno i da nije realno ocijenilo stvarno stanje u Ludbregu, a istu će pogrešku ovo zapovjedništvo ponoviti i tri mjeseca kasnije prilikom napada na Koprivnicu. 
Amir Obhodjaš

THE NEW FINDINGS ABOUT THE WAR IN

NORTHWESTERN CROATIA 1944

Operation „Brod“ and second battle for Ludbreg, July 1944

\section{Summary}

After fierce battles between the Croatian Armed Forces and the Partisan X Corps, that took place in the region of Zagorje from March until May 1944, partisan forces has pulled back to the Moslavina and Kalnik region and intensity of fighting in Northwestern Croatia has significantly dropped down. Relative calm down lasted till mid of Jun when the Partisan $\mathrm{X}$ corps began to concentrate towards the Podravina region in the attempt to seize towns of Koprivnica and Lubreg before the onset of coming winter. At the beginning of July, the bulk of NX Corps reinforced with $28^{\text {th }}$ Division from the VI Corps has been concentrated in the region of Western $\mathrm{Bi}$ logora and Kalnik Mountain with the attempt to seize the town of Koprivnica first. Intelligence reports showed that the town is to heavily fortified, so the command of X Corps has made decision to attack Ludbreg instead. This concentration of partisan forces has not gone unnoticed by the Croatian Armed Forces and they launched operation "Brod" in the attempt to disperse the enemy. Operation failed and preparation for the partisan attack on the town of Lubreg continued only with minor delay. Using the new found documents in Croatian State Archives the author try to bring more perspective to this operation and the subsequent partisan failed attack on Lubreg, which has brought some controversy in the Yugoslavian historiography. 